\title{
Of 'Raisins' and 'Yeast.' Mobilisation and framing in the East German revolution of 1989
}

\author{
Gareth Dale (draft)
}

There is no shortage of literature on the social movements that arose in East Germany in 1989. Numerous studies have shed light upon the nature, scale and dynamics of the uprising of that year. But on certain issues questions remain. No consensus exists, for example, on the relationship between the 'civic groups' (New Forum, Democratic Awakening, etc.) and the street protests of the autumn of 1989. Were these simply two facets of a single movement? Or are they better characterised as two distinct streams within the same movement delta? Did the street protests push the civic movement activists into the limelight? Or is it more accurate to say, with Reinfried Musch, that 'the civic movement brought the people onto the streets'? ${ }^{1}$ This paper considers two contrasting interpretations of these issues, and finds both wanting. An alternative interpretation is offered, one that draws upon Marc Steinberg's 'dialogical' development of frame theory.

\section{Did opposition activists play the role of 'movement organisers'?}

The dominant viewpoint is that civic activists were central to the process of mobilisation in 1989. They created focal points at which resistance gathered. They 'brought the people onto the streets.' In Mary Fulbrook's words, it was the 'leaven of dissident groups' which 'began to raise the bread of the largely subordinate masses.' 2 The civic groups were, according to Karsten Timmer, a 'mobilising force,' one that 'offered many thousands of people the opportunity to get involved constructively, and tapping into the ubiquitous sentiment that something must be done.'3

Yet there are many who see the matter otherwise. For Steven Pfaff and Hyojoung Kim, the civic groups remained 'out of step with popular demands' throughout the protest cycle.4 Mark Thompson proposes that 'would-be emigrants started the protests, mass emigration ignited further demonstrations, and demands for unification were the culmination of the revolution.' 5 The 'real revolutionaries' of 1989 were not civic movement supporters but 'exiters, would-be exiters, and those who demanded reunification.' ${ }^{6}$ Perhaps the most prominent critics of the 'dissidents as leaven' thesis are Karl-Dieter Opp and his colleagues, in Origins of a Spontaneous Revolution. In their judgement, organised oppositionists contributed little, if anything, to the emergence and mobilisation of the demonstration movement in Leipzig (the city at the heart of the rising). Their survey data shows that although members of the civic organisations were much more likely to have participated in 'general protests' in the early autumn than were respondents who belonged to no such group, they were only slightly more likely to have taken part in demonstrations.7 Alluding to a 'well-known snowball effect, in which a small number of revolutionaries sparks a mass movement,' they contend that in 1989 protest developed quite differently: 'the few "revolutionaries" in fact remained among

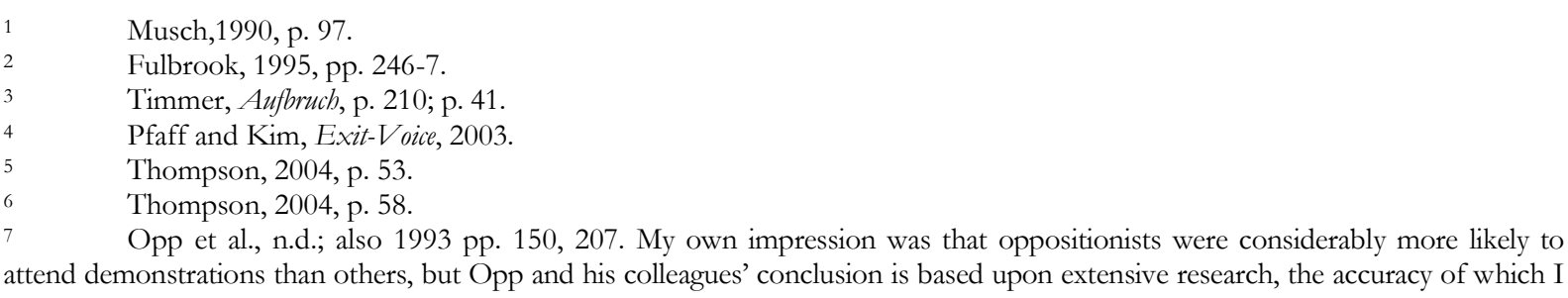
attend demonstrations than others, but Opp and his colleagues' conclusion is based upon extensive research, the accuracy of which I have no reason to doubt. 
themselves'. Far from playing 'an outstanding role' they remained 'marginal' to events. ${ }^{8}$ Their success in 'getting others to protest or of providing incentives for protest [was] very minor. ${ }^{\prime 9}$ Moreover, civic groups failed to encourage those outside their milieu to become "professional revolutionaries.' As Jochen Läßig, a leading member of Leipzig New Forum, recalls:

People came to me and wanted to become members of the New Forum. But I could get very few of them to really embark on political work. [They] signed up as members and were willing to take part in some evening activities, but nobody really wanted to take a personal risk by saying, "Yes, we will invest our energy. We'll forget our professions for a while and invest time in a new organization". ${ }^{10}$

The conclusion for Opp is that East Germany in 1989 was a 'revolution with no head,' a 'revolution without revolutionaries.' 11 The crucial street demonstrations were the products of a 'silent coordination of behaviour,' whereby large numbers of isolated individuals who shared similar grievances 'spontaneously' made the same rational choice: to demonstrate. ${ }^{12}$ Conscious mobilisation of others did take place, but this, to an overwhelming degree, involved forms of 'micro-mobilisation' in which unorganised individuals persuading friends, family members or colleagues to accompany them to Leipzig city centre. It was a 'spontaneous revolution,' and if New Forum was prominent this was not because 'it initiated the mass protests but rather the converse: the masses got their own movement going and pushed New Forum to the fore.' 13

Opp and his colleagues show convincingly that the civic organisations bore little direct responsibility for mobilising individuals to the demonstrations of early October. And there is additional evidence in support of their finding. The organisations were in an embryonic stage of development in the early autumn, as Detlef Pollack has pointed out.

The leading representatives of New Forum and the other civic groups in Leipzig met on 24 September 1989 and agreed to meet next on 22 October-by which time the main phases of the upheaval, such as the replacement of Honecker by Krenz, had already taken place. This indicates that the civic movement not only did not organise the mass protests, but to a considerable extent did not even recognise the urgency of the situation. ${ }^{14}$

Evidence from studies elsewhere in the GDR suggests that these experiences in Leipzig were far from unique. One study of the northern town of Schwerin that inquired into the source of 'the initial impulse for the first mass demonstration' on 23 October discovered that,

although the New Forum group organised the event, they did not initiate it. Instead pressure from within the factories and workplaces throughout the district [...] forced the small New Forum group to act. [...] One of their number recalled 'I can still remember how $M$. came to me and said: "the workers at the Plastmaschinenwerk, they're off, no matter what your group does. The demonstration is now to take place on Monday."'15

Of protest participants whom I interviewed, several recall that in October they were aware of

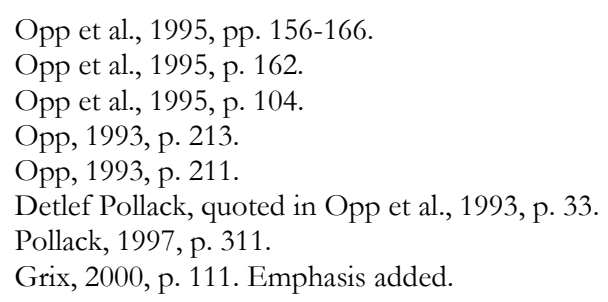


the existence of New Forum but largely ignorant of its goals. Others described their stance towards the civic groups as 'sceptical'. One young Berliner, who described herself as 'kind of Christian,'

never had a good feeling about New Forum. It seemed so vague, expressing no clear position. It gathered together such a disparate bunch of different people that it couldn't give any clear political direction.

In the survey of just over two hundred randomly selected individuals conducted by Lawrence McFalls, a large minority of respondents--45 per cent--had taken part in at least one demonstration, but only 5.5 per cent belonged to a civic organisation. McFalls concludes, in line with Opp et al, that 'the masses got their own movement going and pushed New Forum to the fore'. He illustrates the point with reference to a felicitous metaphor from the questionnaire response of one Greifswald demonstrator: 'The civic groups were like the raisins that happen to sit atop a risen bread dough, exclaiming "Look what I have done!"'16

But even this image may flatter some of the 'raisins'. There are grounds for doubting whether they all felt pleasure and pride as the dough rose. Those civic movement representatives who conceived of their role primarily as a think-tank of reform policies that would be implemented, ideally, through negotiation between themselves and the government saw the demonstrations as a potential threat. "The groups are not seeking to accelerate the rapid dynamic by openly supporting or even calling for demonstrations,' the West Berlin tageszeitung reported; 'the fear of an uncontrolled situation lies deep.'17 Thus, when New Forum declared itself to be an umbrella organisation for all critical forces one member told western journalists that the move was 'rather unfortunate' because it could be construed as declaring the organisation to be a political opposition. ${ }^{18}$ One civic movement leader confessed to fearing the 'force of the population,' and warned that 'we may no longer be able to restrain the demonstrations.' 19 In early October, with the fate of the revolution still in the balance, Rainer Eppelmann, a leader of Democratic Awakening, called on citizens to stay away from demonstrations. ${ }^{20}$ Eberhard Seidel, a founder member of New Forum, insisted that his organisation had 'not set out to organise demonstrations and march through the cities at the head of thousands of people. New Forum's aim is to get dialogue underway.' 'Negotiation,' he added, 'is the decisive factor, and I believe that will take time.'21 His colleague Sebastian Pflugbeil admitted to similar concerns: 'We look at these demonstrations with a very critical eye. They have no form and contours. This worries the security forces and we well understand their concerns.'22

\section{A spontaneous revolution?}

The thesis that the civic groups were the key agents of protest mobilisation is clearly mistaken. Yet the alternative advanced by Opp and his colleagues is not immune to criticism either. Their case rests upon two pillars of argument, both of which are problematic. The first is the assertion that civic movement members 'did not organize the protests; rather, the protests occurred spontaneously.' 23 For Leipzig they go further, maintaining that 'the Monday

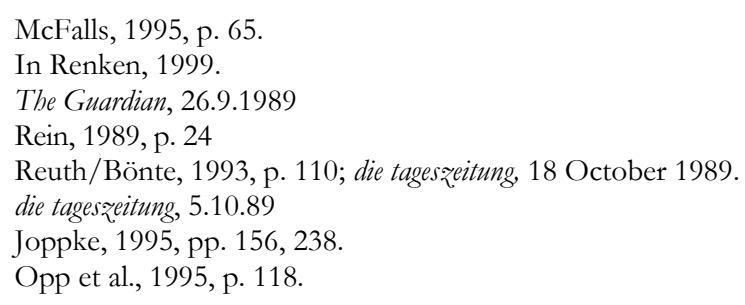


demonstrations were not organized' at all. ${ }^{24}$ The second is that the civic groups did not act as a 'reference group' for the wider population.

These claims are not baseless. It is well known that part of the magic of the Leipzig demonstrations was that they emerged from regular Monday 'peace prayers' in the St. Nicholas Church, an event which appeared to be 'unorganised' or 'spontaneous,' and as such presented the authorities with an intractable problem. As one Stasi Lieutenant-General complained, 'these "peace prayers" don't need to be organized any longer; over months they have become such a customary gathering for these people that they go there completely autonomously.' ${ }^{25}$ Note, however, those two words: 'any longer.' The St. Nicholas Church had not 'spontaneously' become a meeting place for oppositionists but had been actively created as such, by 'movement organisers' over the course of the 1980s. Radical pastors, notably Christoph Wonneberger and Christian Führer, had stood up to the church authorities, and even braved death threats, in order to maintain the St. Nicholas Church as a site at which criticism could be voiced. ${ }^{26}$ Opposition activists had politicised the peace prayers, even when pastors Wonneberger and Führer had counselled caution. And when Führer and church superintendent Friedrich Magirius had eventually succumbed to pressure to cancel the prayers in 1988, oppositionists resisted. Admittedly, it was not opposition activists but emigration applicants who, in early 1989, converted the Monday political worships into protests. But they had only begun to arrive at the peace prayers in large numbers when they observed that oppositionists in Berlin had been expelled from the country as a result of so-called anti-state activity. Moreover, it was from within the opposition milieu that the impetus to transform emigrant-led protests in support of their exit from the country into demonstrations for political change. In short, if one attends to the origins of the Monday demonstrations, it appears that organised oppositionists exploiting external resources - the St. Nicholas Church - played a crucial role.

In addition, it should be noted that outside Leipzig the contribution of oppositionists to organising the protests of the early autumn was outstanding. One researcher, Carsten Johnson, has systematically recorded protest activities in East Germany throughout 1989 and 1990. His findings show that the great majority, at least until October, were organised by 'political groups,' and that only in the last three months of 1990 were the bulk of such events initiated by the 'population.' 27 The mass movement, in Leipzig and elsewhere, emerged from a culture of peace prayers, church meetings and small demonstrations in the 1980s, all of which were strongly influenced, and in many cases instigated by, opposition activists, many of whom went on to form the core of the civic movement. ${ }^{28}$

A second shortcoming of the position advanced by Opp et al. concerns the indirect relations between civic movement and demonstrators. In their view, the civic movement did not act as a 'reference group' - a term they use to designate organisations 'that contributed to the development of protest simply by means of their existence.' Rather, they insist, 'most GDR citizens were unaware of the exact goals and activities of the opposition groups.'

Their evidence for this is thin, ${ }^{29}$ but if the word exact is taken literally, the claim is almost irrefutable. What I would take issue with is the ensuing conclusion: that, by virtue of their partial ignorance, East Germans 'could not identify with these groups.' 30 Why citizens must be cognisant of the exact goals and activities of a group in order to identify with it is not spelt

Opp et al., 1995, p. 23.

Zwahr, 1993, p. 20

On the history of the peace prayers, see Wagner, ed. 1994, especially the introduction; also Pfaff, 2001.

Johnson 1992 p. 89, also Johnson, n.d.

In Leipzig for example, the founders of NF all came from groups that had organised demonstrations in previous years. Fehr, 1996, p. 232.

$29 \quad$ One part of their evidence refers to the time prior to May 1989; the other is the recollection of one interviewee who had heard of New Forum but did not 'really know what it was'. Opp, Vo $\beta$ and Gern, 1995, p. 105.

$30 \quad$ Opp et al. 1995 p. 118. Emphasis added. 
out. Indeed, in a different section of Origins of a Spontaneous Revolution the authors seem to appreciate that this is the case. Discussing survey respondents' attitudes to the Church, they find that, despite the ambivalent and at times hostile attitude of Church leaders towards opposition and protest, 'many GDR citizens have probably identified with the goals of the Protestant Church because of its somewhat critical stance toward the SED regime.'31 The Church was too fractured for any clear, let alone exact, picture of its goals and activities to be drawn, and yet Opp et al. nonetheless feel that an unambiguous conclusion is warranted: 'This identification [of East Germans with the Church] promoted participation in the protests.' Compare this with their reluctance to accept that ordinary citizens may have identified with the civic movement. Are double standards being applied? It is difficult to conclude otherwise.

As these examples indicate, identification is a complex and shifting process. Identification with an organisation can exist to a significant degree even in the absence of comprehensive knowledge of its aims. Citizens can rally to the flag of a social-movement organisation even if they are only dimly aware of its agenda. And this, it seems to me, is a useful way of conceiving of the relationship between East Germans and the civic movement: activists designed and planted the flag; its image was disseminated, by civic movement supporters and the West German media; large numbers came to identify with it. Let us turn to look at these processes in detail.

As platforms claiming national scope, the civic groups assembled into a central force activists whose primary identification had hitherto been to local church-based groups, as well as wider layers with no political experience. From mid-September 1989 they were transformed from formal platforms into active forces, in the form of members connected through structures. Existing oppositional groups regrouped around civic organisations, and spread word of their actions through existing networks. Large meetings in cities attracted individuals from surrounding towns, who would return home to set up similar events. Up and down the country, oppositionists and their friends got to work gathering signatures and printing and distributing leaflets, often at considerable risk. One New Forum organiser concealed lists of supporters in an envelope under his pillow-until it became so fat that he had to find somewhere else to hide it. ${ }^{32}$ Uwe Rottluf, a printer in the postal service-who found himself 'in partial agreement with New Forum' - printed out a bale of leaflets at work, as a favour for a colleague. ${ }^{33} \mathrm{Next}$, leaflets were passed on to friends, surreptitiously placed in prominent places or handed around at work. Donations were collected to support campaigns for detained demonstrators. Activities were also publicised, often with extraordinary success, via 'whisper propaganda.' One Stasi document from the Potsdam area-representative of many from late September and early October - warned that:

Awakening '89, as well as calls for support for the 'Initiative New Forum,' are being distributed by means of the misuse of cultural and other meetings, shop windows, wall newspapers, educational establishments and the Church, as well as by word of mouth and by the painting of enemy grafitti-all of which proceeds without the perpetrators meeting significant resistance.

These acts, the report concluded, have led to 'large sections of the population developing an interest in New Forum's proposals.' Their activists, it continued, 'feel strengthened and protected by this "positive" resonance amongst the population.' 34

That the addresses of New Forum's founder members were published on their

Opp et al. 1995 p. 135. Emphasis added.

Grix 2000 p.111

Interview with the author. ('The state was not so omniscient!', he commented wryly.)

Meinel and Wernicke, 1990, pp. 141-2. 
materials soon led to their homes attracting thousands of sympathisers - despite the high risk of arrest that accompanied such behaviour. On one day alone, Bärbel Bohley's flat in Berlin was visited by 190 people. ${ }^{35}$ At the home of Berlin New Forum's Tina Krone, she recalls,

queues of people would be waiting on the stairs, every day! They continued into the evening, sometimes as late as 2:30 a.m. Some poured out their life stories to us; others would say "We want to do X, Y or Z: how did you do it?"

In Leipzig, a New Forum supporter has described how three members each gave their addresses as contact points, and when they 'discovered that we were no longer able to deal with the flood [of inquiries] - people would come for information even in the small hours' they were obliged to expand the circle of organisers. ${ }^{36}$ At another, in Magdeburg, in HansJoachim Tschiche's evocative description, visitors 'engaged in inflamed discussion; often, forty people and more filled all the rooms; cigarette smoke hung in the air; the doors were still swinging long after midnight. It was euphoric.' 37

Hives of organisation and debate also formed in churches and church halls. I recall visiting one, at the Gethsemane church in Berlin. Outside, a candlelight vigil demanding the release of those arrested on demonstrations. Within, several hundred people reading, or queuing to read, civic movement propaganda. Whether in churches or in front rooms, these sites of organisation and discussion were known as contact centres. They were meeting places at which like-minded spirits would gather, helping to create a generalised and actualised awareness of common cause. They acted as transformers, raising the voltage of opposition.

Meanwhile, letters poured in to the contact centres, conveying myriad hopes, concerns, demands, or simply greetings. 38 'What should I do?' 'How can I get active?,' were typical questions. One, from a rail worker in Frankfurt an der Oder, read as follows:

As I walked past the main post office I noticed a group of people. A New Forum statement was pinned up there! At last I had found what I had been looking for for weeks: contact addresses. Please send me information, for my colleagues and neighbours have so many questions about New Forum.

Another correspondent wrote to Dr. Tietze of New Forum of his 'elation' at hearing news of Awakening '89. 'Thank you for your courage!' was a common phrase. 'Warmest thanks for your leaflet,' read another; 'It has filled me once again with a hope that had, I thought, gone for good.' Many other correspondents proposed issues that the opposition might take up, some of which were general, others quite specific (in one case even down to the price that a loaf of bread should cost - 'Three Marks and fifty Pfennig!' the correspondent insisted).

By means of leafleting, petitioning, the contact centres, and the amplification effect of these activities through West German television and radio broadcasts, very large numbers did become aware of the existence and aims of the civic groups. A typical experience is that of Ollie, an interviewee who described himself as having been 'not very political,' and mistrustful of organisations -'I'm the kind of guy who stays quiet most of the time but I turn stubborn when challenging something I don't like.' Ollie's memories are of

New Forum leaflets that found their way, somehow, into our apprentice's hostel. Nobody knew where they had come from - but we read them and discussed

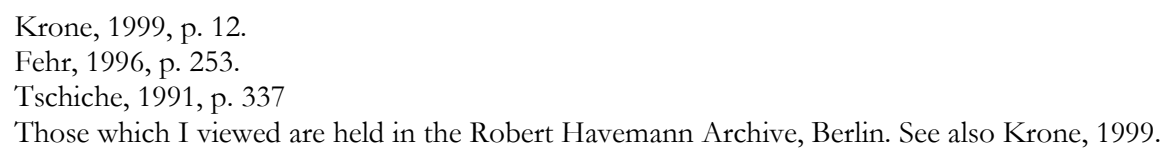


them. It was all very interesting and so very new. "Wow," I thought, "What these say is actually so logical. Why did I never think of that myself?"

Ollie knew no oppositionists, did not contact New Forum nor attended any of their meetings. Yet he clearly did identify with aspects of their aims and analysis and found encouragement in the process. The circulation of Awakening ' 89 in particular strengthened the impression amongst those who heard of and read it that a movement was crystallising, that demands for immediate and real change were now on the table. It acted as a focus for hopes in political change and a stimulus to work towards alternative perspectives. It helped to fire tens of thousands with a sense of shared purpose, a belief that change was possible, thus raising their confidence and commitment to movement building. As one young woman put it, Awakening '89 'really was a clarion call. I was electrified.' ${ }^{39}$ Similarly, a young Berliner, Antje Neubauer, recalled, 'When I heard of New Forum it gave me a greater sense of confidence that things would work out-although I still couldn't imagine that it would ever be legalised.'

From the above, it seems that the important question to explore is less that of whether or not the civic groups 'mobilised the populace' but the character of their activity. Here, a useful distinction can be made between agitation and propaganda - or, in Bert Klandermans' terminology, action mobilisation and consensus mobilisation. The former refers to the process by which an organization in a social movement calls up people to participate.' 40 It includes the taking of decisions as to times, places and themes of activities, and the methods used to encourage attendance. The latter refers primarily to the dissemination of goals and of general arguments as to how these might be achieved. It 'is a process through which a social movement tries to obtain support for its viewpoints.' Although civic organisation members did mobilise for action, there is little doubt that their strongest suit was propaganda. In the vocabulary of David Snow and Robert Benford, they propagated a 'master frame' that helped their audience orient themselves to the unfolding political crisis.

In social movement theory a frame is 'an interpretive schema that signifies and condenses the "world out there" by selectively punctuating and encoding objects, situations, events, experiences and sequences of action in one's present or past environment.'41 Collective action frames serve as 'accenting devices that either underscore and embellish the seriousness and injustice of a social condition or redefine as unjust and immoral what was previously seen as unfortunate but perhaps tolerable.'42 In addition to offering an interpretation of events, they entail diagnostic and prognostic attributions, thereby enabling activists 'to articulate and align a vast array of events and experiences so that they hang together in a relatively unified and meaningful fashion.' ${ }^{43}$ They present political problems as being determined or at least largely conditioned by the dynamics of the social order, thereby demonstrating the potential for modification through collective action.

Awakening ' 89 fulfilled several vital framing functions. It presented an interpretation of the political impasse in clear and comprehensible language, and it staked New Forum's claim, on behalf of the population, to be 'part owner' of the country's crisis, asserting the right to contribute to its resolution. ${ }^{44}$ By referring to the chasm between 'state and society' it hinted that chief culpability was the regime's, and that 'something should be done' to improve 'communication,' construct an open public sphere and pave the way towards a more democratic society. The frame of Awakening '89 'resonated' widely. It keyed into the widespread desires for political change and the demands that the regime begin to listen to,

Probst, 1991, p. 46

Klandermans, 1984, p. 586. See also Johnson and Wielgohs, 1997.

Quoted in Steinberg, 1998, p. 845. See also Snow et al., 1986 and Snow and Benford, 1992

Steinberg, 1998 , p. 845.

Snow and Benford 1992 p. 136-8.

Diani and della Porta, 1999, p. 70 
and engage in dialogue with, the citizenry.

In these ways consensus mobilisation by the civic groups fed into action mobilisation. Their forward-looking frame, the pitch that popular pressure could contribute to political reform, helped to ferment the belief in wide layers of the population that something could at last be done, and that they themselves could play a part. Thousands of individuals now felt connected through a shared political and oppositional identity. This process of identification with a national platform strengthened the norms of engagement and solidarity that were so important in the early, anxious stages of the revolt. The civic movement networks thus helped to bring confidence to protestors far beyond their own ranks. Their branches mobilised resources, in the form of people, venues, communications, propaganda materials, and coordinated activities and information exchange across the country. They fed news to the western media, and helped to spark public political debate. In Karsten Timmer's words, the civic movement was indeed a mobilising force: 'It offered many thousands of people the opportunity to get involved constructively, it tapped into the ubiquitous sentiment that something must be done. ${ }^{45}$ Although not directly responsible for the mobilisation of the large Leipzig crowds of early October the civic movement nonetheless played a major role in generating a positive, buoyant culture of protest.

One caveat should, however, be added at this stage of the argument. To say that the civic movement influenced the wider 'culture of protest' tells us little about the nature of that influence. Was it of a transitive kind, with the social movement organisations as agents, the broader culture as object? A good part of the literature on framing makes precisely this assumption. But as Marc Steinberg has recently proposed the relationship is better conceived as 'dialogical.' 46 In the East German case, the protest culture 'out there' had a powerful bearing upon the nature and self-conception of the civic movement. Groups such as New Forum evolved in interaction with their supporters and with the wider public. The initial self-conception of its founder members was simply as a platform. But as it was adopted by protestors as a symbol of opposition this began to change. Of the letters that flooded in to the contact centres some referred to New Forum not as a mere 'platform' but as a 'movement'. On the streets, protestors appropriated the names and (selected) ideas of the civic movement as their own, as a 'banner' to wave against the regime; and this, in turn, cemented the popularity and repute of the civic groups. The critical moment came when Leipzig demonstrators, who had previously chanted 'We're staying here!' as a (courageous but directionless) counter-slogan to the emigrants' 'We want out!' began to raise that concrete demand, 'Legalize New Forum!,' which quickly became one of the most prevalent slogans in September and early October, and helped to impart New Forum with a 'movement identity' of street protest. In such ways, New Forum became a 'flag' that indicated an oppositional stance. When a group of youths returning home from a disco in Prenzlau stopped to tear down some GDR emblems, they were heard to shout 'Up with New Forum - Stasi out!'47 Similarly, Andrea, a secretary from Berlin recalls that

My gut reaction to New Forum was positive - even though I knew very little about them. I just thought: "they're oppositionists, they're against the state, that's good." So when I went to Leipzig to the demonstration there I chanted "Legalise New Forum!"

At the Leipzig demonstrations in late October, by which time some 100,000 had signed Awakening '89, New Forum, 'although few in numbers' was, according to one witness, 'thoroughly in charge. Whenever the words "Here Speaks the New Forum" were uttered

Timmer, 2000, p. 210.

Steinberg, 1998, 1999.

Langer 1999 p. 120 
through the megaphone, the people cheered loudly and gathered round the speaker.' ${ }^{48} \mathrm{~A}$ month later, a West German polling institute found that over 30 per cent of respondents indicated that, if asked to vote, they would cast theirs for one or other civic group, with New Forum being the most popular political organisation in the country. ${ }^{49}$ The conclusion is inescapable: the civic movement helped to create an activist, optimistic protest culture. Their coming into being represented 'the signal for an attack on the SED's power monopoly, and with that, the signal for a general uprising. ${ }^{50}$ They played a small but significant role in dispelling the clouds of resignation and fear that had held back participants from protest. Their rapid rise to public prominence was 'raisin like' but, in addition, they acted as 'yeast.'

\section{$\underline{\text { References }}$}

Hannes Bahrmann and Christoph Links (1994) Chronike der Wende, Berlin: Links.

Mario Diani and Donnatella della Porta (1999) Social Movements: An Introduction, Oxford: Blackwell.

Helmut Fehr (1996) Unabhängige Öffentlichkeit und soziale Bewegungen. Fallstudien über Bürgerbewegungen in Polen und der DDR, Opladen.

Mary Fulbrook (1995) Anatomy of a Dictatorship, Oxford: Oxford University Press.

Bernd Gehrke, (2001) 'Demokratiebewegung und Betriebe in der "Wende" 1989. Plädoyer für einen längst fälligen Perspektivwechsel?' in Gehrke and Renate Hürtgen, eds., Der betriebliche Aufbruch im Herbst 1989: Die unbekannte Seite der DDR Revolution, Berlin: Bildungswerk.

Jonathan Grix (2000) The Role of the Masses in the Collapse of the GDR, Macmillan.

Carsten Johnson (1992) Massenmobilisierung in der DDR im Jahre 1989, M.A. Thesis, Freie Universität Berlin.

Carsten Johnson (n.d.) Collated data on protest activities GDR 1989-90, in possession of the author.

Christian Joppke (1995) East German Dissidents and the Revolution of 1989, Basingstoke: Macmillan.

Bert Klandermans (1984) 'Mobilization and Participation: Social-Psychological Expansions of Resource Mobilization Theory' American Sociological Review, Vol. 49, 583-600.

Tina Krone, ed. (1999) "Sie haben so lange das Sagen, wie wir es dulden”; Briefe an das Neue Forum September 1989-März. 1990, Berlin: Robert-Havemann-Gesellschaft.

Kai Langer (1999) "Ihr sollt wissen, daß der Norden nicht schläft..." Zur Geschichte der "Wende" in den drei Nordbezirkeen der DDR, Bremen: Edition Temmen

Laurence McFalls (1995) Communism's Collapse, Democracy's Demise?, Houndmills: Macmillan.

Reinhard Meinel and Thomas Wernicke, eds, (1990) Mit tschekistischem Gruß, Potsdam: Edition Babelturm.

Reinfried Musch (1990) 'Die Linke und die Revolution in der DDR,' in Axel Lochner, ed., Linke Politik in Deutschland, Hamburg: Galgenberg.

Karl-Dieter Opp et al. (1993) Die volkseigene Revolution, Stuttgart: Klett-Cotta.

- (n.d.) Eine Umfrage über die Entstehung und den Verlauf der Proteste in der DDR 1989-1990, Unpublished data, in possession of the author.

- (1995) Origins of a Spontaneous Revolution: East Germany, 1989, Ann Arbor.

Steven Pfaff (2001) 'The Politics of Peace in the GDR: The Independent Peace Movement, the Church, and the Origins of the East German Opposition', Peace and Change, Vol. 26, No. 3.

Steven Pfaff and Hyojoung Kim (2003) 'Exit-Voice Dynamics in Collective Action: An Analysis of Emigration and Protest in the East German Revolution,' American Journal of Sociology, (109) 2, 401-44.

Detlef Pollack (1997) 'Bedingungen der Möglichkeit politischen Protestes in der DDR,' in Detlef Pollack and Dieter Rink, eds, Zwischen Verweigerung und Opposition, Frankfurt/Main: Campus.

Lothar Probst (1991) Bürgerbewegungen und politische Kultur, Bremen: Institut für kulturwissenschaftlichen Deutschlandstudien.

Gerhard Rein, ed. (1989) Die Opposition in der DDR, Berlin: Wichern.

Frank Renken (1999) Die Rolle der Oppositionsgruppen in der ostdeutschen Revolution 1989/1990, Masters dissertation, Freie Universitat Berlin.

Ralf Georg Reuth and Andreas Bönte (1993) Das Komplott, München: Piper.

Joppke, 1995, p. 156.

Bahrmann and Links 1994 p. 120

Gehrke, 2001, p. 226 
Uwe Schwabe (1999) 'Die Entwicklung der Leipziger Opposition in den achtziger Jahren,' in Günther Heydemann et al, Revolution und Transformation in der DDR, Berlin: Duncker and Humblot.

David Snow et al. (1986) 'Frame Alignment Processes, Micromobilization, and Movement Participation,' American Sociological Review, 51:464-81.

David Snow and Robert Benford (1992) 'Master Frames and Cycles of Protest,' in Aldon Morris and Carol McClurg Mueller, eds, Frontiers in Social Movement Theory, New Haven: Yale University.

Marc Steinberg (1999) 'The Talk and Back Talk of Collective Action: A Dialogic Analysis of Repertoires of Discourse among Nineteenth-Century English Cotton Spinners,' American Journal of Sociology, 105 (3): 736-80.

Marc Steinberg (1998) 'Tilting the Frame: Considerations on Collective Action Framing From a Discursive Turn,' Theory and Society, 27: 845-872.

Mark Thompson (2004) Democratic Revolutions. Asia and Eastern Europe, London, Routledge.

Karsten Timmer (2000) Vom Aufbruch zum Umbruch. Die Bürgerbewegung in der DDR 1989, Göttingen: Vandenhoeck \& Ruprecht.

Hans-Joachim Tschiche (1991) 'Herbst 1989 in Magdeburg,' in Anstiftung zur Gewaltlosigkeit, Magdeburg: Impuls Verlag.

Harald Wagner, ed., (1994) Freunde und Feinde, Leipzig: Evangelische Verlagsanstalt.

Jan Wielgohs and Carsten Johnson (1997) 'Entstehungsgründe, Handlungsbedingungen, Situationsbedeutungen,' in Detlef Pollack and Dieter Rink, eds., Zwischen Verweigerung und Opposition, Frankfurt/Main: Campus.

Hartmut Zwahr (1993) Ende einer Selbstzerstörung, Göttingen: Vandenhoek \& Ruprecht. 